\title{
PENGEMBANGAN PANDUAN PRAKTIKUM KIMIA DASAR BERBASIS SALINGTEMAS UNTUK MAHASISWA S1 PENDIDIKAN IPA UNIVERSITAS BHINNEKA PGRI
}

\author{
Rohmatus Syafi'ah ${ }^{1 *}$, Alik Mustafidal Laili², \\ Muhamad Amrul Wafa ${ }^{3}$ \\ 1,2,3 Universitas Bhinneka PGRI \\ *Corresponding Author: syafiahzainul@gmail.com
}

DOI: $10.24929 /$ lensa.v11i2.170

Received: 8 Juli $2021 \quad$ Revised: 15 Oktober $2021 \quad$ Accepted: 15 Oktober 2021

\begin{abstract}
ABSTRAK
Matakuliah yang masuk ke dalam rumpun Ilmu Pengetahuan Alam (IPA) salah satunya adalah matakuliah Kimia dasar. Salah satu cara untuk mengajarkan ilmu kimia secara utuh adalah melalui kegiatan praktikum. Hambatan dalam pelaksanaan kegiatan praktikum pada matakuliah praktikum kimia dasar di Universitas Bhinneka PGRI adalah belum tersedianya panduan praktikum. Pengembangan panduan praktikum kimia dasar berbasis Sains, Lingkungan, Teknologi, dan Masyarakat (SALINGTEMAS) ini adalah salah satu upaya yang dapat dilakukan untuk mengatasi hambatan tersebut. Tujuan pengembangan panduan praktikum ini adalah untuk mengembangkan dan mendeskripsikan kelayakan produk pengembangan berupa panduan praktikum kimia dasar berbasis SALINGTEMAS. Ada empat tahapan dalam proses pengembangan modul ini yaitu pada tahap pertama menyusun kerangka panduan praktikum berdasarkan dari pengembangan alat, spesifikasi, dan standarnya; tahap kedua yaitu mencocokkan panduan praktikum yang sudah dikembangkan dengan kerangkanya; tahap ketiga yaitu meninjau dan memperbaiki panduan praktikum yang sudah dikembangkan; dan tahap keempat yaitu mengimplementasikan produk akhir dari panduan praktikum. Hasil dari penelitian ini menunjukkan bahwa panduan praktikum kimia dasar berbasis SALINGTEMAS yang telah dikembangkan memperoleh persentase uji kelayakan oleh ahli materi sebesar $88 \%$ dan ahli media sebesar $84 \%$. Persentase rata-rata respon mahasiswa sebesar $84 \%$. Artinya, panduan praktikum kimia dasar berbasis SALINGTEMAS layak digunakan dalam proses pembelajaran.
\end{abstract}

Kata Kunci : Kimia Dasar; Panduan Praktikum; Pendidikan IPA; SALINGTEMAS

\section{ABSTRACT}

One of the subjects that are included in the Natural Sciences (IPA) group is the Basic Chemistry course. One way to teach chemistry as a whole is through practical activities. The obstacle in carrying out practical activities in basic chemistry practicum courses at the University of Bhinneka PGRI is the unavailability of practical guides. The development of a basic chemistry practical guide based on Science, Environment, Technology, and Society (SALINGTEMAS) is one of the efforts that can be made to overcome these obstacles. The purpose of developing this practicum guide is to develop and describe the feasibility of a product development in the form of a basic chemistry practicum guide based on SALINGTEMAS. There are four stages in the process of developing this module, namely in the first stage preparing a practicum guide framework based on the development of tools, specifications, and standards; the second stage is to match the practicum guide that has been developed with the framework; the third stage is to review and improve the practicum guide that has been developed; and the fourth stage is implementing the final product of the 
practicum guide. The results of this study indicate that the SALINGTEMAS-based basic chemistry practicum guide that has been developed obtains a percentage of feasibility tests by material experts by $88 \%$ and media experts by $84 \%$. The average percentage of student responses is $84 \%$. That is, the basic chemistry practicum guide based on SALINGTEMAS is suitable for use in the learning process.

\section{Keywords: General Chemistry, Practical Guide, Science Education, SALINGTEMAS}

\section{PENDAHULUAN}

Ilmu kimia di tingkat universitas salah satunya dipelajari melalui matakuliah kimia dasar. Ilmu kimia merupakan ilmu yang bersifat abstrak (Mahfuzah,dkk., 2018), sehingga banyak mahasiswa yang merasa kesulitan dalam mempelajarinya. Matakuliah kimia dasar merupakan matakuliah keprodian yang wajib ditempuh oleh mahasiswa S1 Pendidikan IPA Universitas Bhinneka PGRI. Matakuliah ini merupakan bagian dari ilmu IPA yang merupakan ilmu yang berlandaskan metode ilmiah dan eksperimen. Oleh karena itu, adanya petunjuk praktikum menjadi hal yang sangat penting dalam matakuliah kimia dasar. Perkuliahan teori maupun praktikum harus ditingkatkan sejak tahun pertama perkuliahan sebagai bekal bagi mahasiswa calon guru IPA dimana guru IPA dituntut untuk mampu menjelaskan teori ataupun melakukan kegiatan praktikum IPA yang di dalamnya meliputi fisika, kimia, dan biologi. Dalam mempelajari IPA khususnya ilmu kimia terdapat dua hal pokok yang harus dipahami mahasiswa yaitu ilmu kimia sebagai proses dan produk (BNSP, 2006). Untuk mencapai pemahaman yang utuh tentang ilmu kimia kedua hal pokok yang tersebut tidak dapat dipisahkan. Salah satu cara untuk mengajarkan ilmu kimia secara utuh adalah melalui kegiatan praktikum.

Mahasiswa mampu berlatih bekerja sebagai seorang ilmuan melalui kegiatan praktikum dengan melakukan percobaan ilmiah, menerapkan cara kerja dan sikap ilmiah untuk menemukan suatu konsep. Oleh karena itu, untuk mengembangkan aktivitas mahasiswa (menemukan fakta, melakukan percobaan, memecahkan masalah dengan pendekatan ilmiah, pengamatan, menyampaikan hasil pengamatan, dan penemuan konsep) khususnya dalam matakuliah kimia dasar dikutkan dengan matakuliah praktikum kimia dasar dengan metode praktikum (Murtidkk., 2014). Dalam hal ini, dosen berperan sebagai fasilitator, memberikan penguatan konsep, dan memberikan koreksi pada konsep yang masih belum tepat. Salah satu sarana yang diperlukan untuk mempermudah mahasiswa dalam melakukan kegiatan praktikum di laboratorium adalah panduan praktikum. Untuk membantu mahasiswa berlatih kerja ilmiah dan keterampilan proses sains diperlukan pengembangan panduan praktikum (Prayitno, 2017).

Salah satu hambatan dalam pelaksanaan kegiatan praktikum pada matakuliah praktikum kimia dasar di Universitas Bhinneka PGRI adalah tidak tersedianya laboratorium kimia serta alat dan bahan kimia yang mengakibatkan tidak berlangsungnya suatu topic praktikum. Mengembangkan panduan praktikum kimia dasar berbasis SALINGTEMAS merupakan salah satu upaya yang dapat dilakukan untuk mengatasi hambatan tersebut. Pada dasarnya lingkungan sekitar yang tidak terlepas dari sains, teknologi dan masyarakat merupakan sarana untuk belajar kimia. Panduan praktikum kimia dasar berbasis SALINGTEMAS diperlukan agar mahasiswa memahami implikasi hubungan antar unsur SALINGTEMAS dalam matakuliah kimia dasar, serta diharapkan mahasiswa mampu berfikir ilmiah, menerapkan prinsipprinsip dan cara kerja ilmiah dalam memecahkan masalah lingkungan (Binadja, 1999). Selain itu, alasan kami mengembangkan panduan praktikum berbasis SALINGTEMAS ini karena belum adanya panduan praktikum khusunya kimia dasar yang berbasis SALINGTEMAS, yang ada yaitu pengembangan bahan ajar (LKS) berbasis SALINGTEMAS (Kadir, 2017).

Berdasarkan permasalahan yang di atas, tujuan penelitian ini adalah untuk mendeskripsikan pengembangan dan kelayakan panduan praktikum kimia dasar berbasis SALINGTEMAS untuk mahasiswa S1 pendidikan IPA Universitas Bhinneka PGRI. Dengan adanya modul praktikum ini, diharapkan akan mempermudah 
mahasiswa dalam melaksanakan proses perkuliahan praktikum kimia dasar dengan topik Pengenalan dan Identifikasi Alat dan Bahan Kimia, Campuran homogen dan Heterogen, Pembuatan Larutan, Reaksi Reduksi Oksidasi, Sel Elektrokimia, Kalorimetri (Penentuan Kalor Jenis Logam), dan Laju Reaksi.

\section{METODE}

Model pengembangan yang digunakan pada penelitian ini terdiri dari empat tahapan yaitu tahap pertama menyusun sebuah kerangka dari pengembangan alat, pengembangan spesifikasi, dan standarnya; tahap kedua mengembangkan bagian bagian dari media yang telah dicocokkan dengan kerangkanya; tahap ketiga meninjau dan memperbaiki produknya; dan tahap keempat mengimplementasikan produk akhirnya (William W. Lee dan Diana L. Owens, 2004). Alur penelitian dapat dilihat pada gambar diagram di bawah ini.

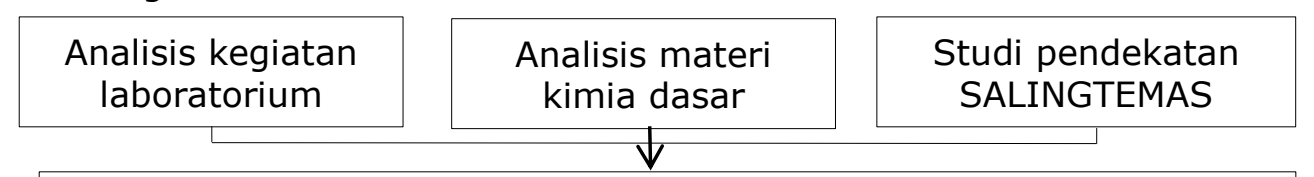

1) Menyusun kerangka dari pengembangan panduan praktikum kimia dasar

V

2) Mengembangkan panduan praktikum kimia dasar yang sesuai dengan kerangka

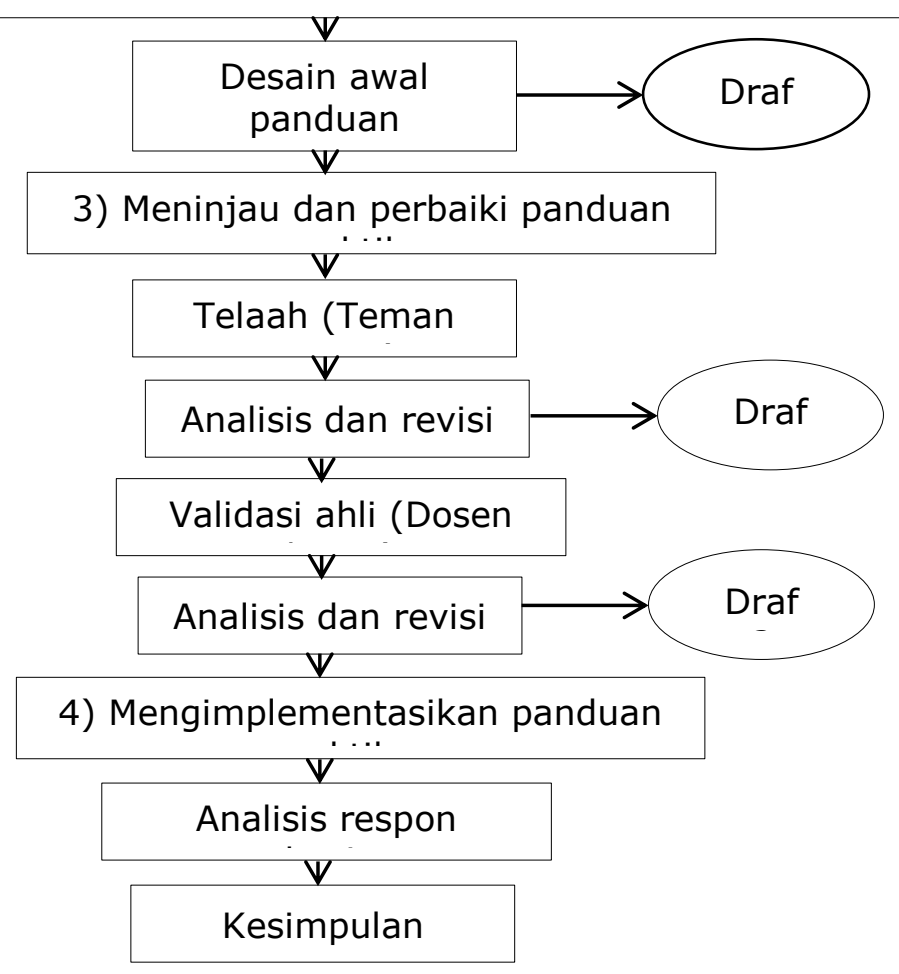

Gambar 1. Diagram Model Pengembangan Panduan praktikum Kimia Dasar Berbasis SALINGTEMAS

Pada tahap pertama yaitu menyusun kerangka dari panduan praktikum kimia dasar berbasis SALINGTEMAS kemudian menganalisis materi kimia dasar serta studi terhadap prinsip pendekatan SALINGTEMAS. Adapun tujuan dari analisis ini untuk mengumpulkan informasi terkait dengan kebutuhan panduan praktikum yang akan dikembangkan. Analisis kegiatan laboratorium dilakukan dengan obervasi secara langsung alat dan bahan serta mengetahui kegiatan praktikum yang berlangsung di laboratorium IPA. Selanjutnya menganalisis isi materi yang ada di Rencana Pembelajaran Semester (RPS) yang telah divalidasi oleh tim kurikulum Universitas Bhinneka PGRI. Langkah selanjutnya yaitu melakukan studi pendekatan 
SALINGTEMAS untuk menentukan prinsip yang disesuaikan dengan prosedur setiap judul praktikum.

Tahap yang kedua yaitu mengembangkan panduan praktikum kimia dasar berbasis SALINGTEMAS yang telah disesuaikan dengan kerangka pada tahap pertama yang disebut dengan draf 1 . Selanjutnya yaitu meninjau draft 1 melalui proses telaah oleh teman sejawat. Dari hasil telaah tersebut, draft 1 direvisi sesuai saran yang telah diberikan oleh teman sejawat dan dihasilkan draf 2. Draft 2 tersebut kemudian divalidasikan kepada 2 validator ahli media dan 2 validator ahli materi untuk mengetahui kelayakannya. Dari hasil validasi tersebut kemudian direvisi sesuai dengan masukan dari validator hingga akhirnya menghasilkan draf 3 yang siap diimplementasikan pada tahap uji coba kepada mahasiswa S1 Pendidikan IPA Universitas Bhinneka PGRI (sejumlah 5 responden).

Instrumen yang digunakan pada penelitian ini ada 3 yaitu lembar validasi ahli materi, lembar validasi ahli media, dan angket respon mahasiswa. Lembar validasi untuk ahli materi terdiri dari 10 pernyataan, lembar validasi untuk ahli media terdiri dari 9 pernyataan, dan angket respon untuk mahasiswa terdiri dari 12 pernyataan. Validator ahli materi sejumlah 2 orang, validator ahli media sejumlah 2 orang, dan responden sejumlah 5 mahasiswa. Alasan kami menggunakan 5 responden karena dalam 1 kelas yaitu pada semester 2 jumlah mahasiswa 5 orang. Untuk skor maksimum yang dapat diperoleh dari ahli materi yaitu $5 \times 10=50$, dan skor maksimum yang dapat diperoleh dari ahli media yaitu $5 \times 9=45$. Sedangkan skor maksimum yang dapat diperoleh dari angket respon mahasiswa yaitu $5 \times 12=60$. Dengan menggunakan skala Likert sebagai berikut:

\begin{tabular}{cc} 
Tabel 1. Skala Likert & \\
\hline Kriteria & Skor \\
\hline Sangat baik & 5 \\
\hline Baik & 4 \\
\hline Cukup baik & 3 \\
\hline Kurang baik & 2 \\
\hline Sangat tidak baik & 1 \\
\hline
\end{tabular}

(Sugiyono, 2017)

Hasil lembar validasi dan angket respon mahasiswa selanjutnya diubah ke dalam bentuk persentase. Hasil persentase yang diperoleh tersebut dikonversi dalam kriteria kelayakan (Murdiani, 2012) berdasarkan pada Tabel 2 berikut ini.

Tabel 2. Kriteria Kelayakan Panduan Praktikum

\begin{tabular}{cc}
\hline Persentase (\%) & Kriteria \\
\hline $81,26-100$ & Sangat Layak \\
\hline $62,51-81,25$ & Layak \\
\hline $43,76-62,50$ & Cukup Layak \\
\hline $25-43,75$ & Tidak Layak \\
\hline
\end{tabular}

Berdasarkan kriteria di atas panduan praktikum kimia dasar berbasis SALINGTEMAS yang telah dikembangkan dapat dianalisis dan dapat ditarik kesimpulan bagaimana kualitasnya.

\section{HASIL DAN PEMBAHASAN}

Tahapan proses Pengembangan Panduan Praktikum Kimia Dasar Berbasis SALINGTEMAS adalah sebagai berikut:

a. Analisis Kegiatan Laboratorium

Analisis kegiatan laboratorium dilakukan dengan cara observasi dan mengelist alat dan bahan apa saja yang tersedia dalam laboratorium kemudian disesuiakan dengan materi Kimia Dasar yang ada di dalam Rencana Pembelajaran Semester (RPS). Berikut merupakan list alat dan bahan yang tersedia di dalam laboratorium IPA Universitas Bhinneka PGRI yang dapat digunakan untuk kegiatan praktikum Kimia Dasar. 
Tabel 3. Analisis Kegiatan Laboratorium yang Sesuai dengan Alat dan Bahan yang Tersedia di Laboratorium IPA Universitas Bhinneka PGRI

\begin{tabular}{clll}
\hline No. & \multicolumn{1}{c}{ Alat } & \multicolumn{1}{c}{ Bahan } & \multicolumn{1}{c}{$\begin{array}{c}\text { Kegiatan Laboratorium } \\
\text { yang Bisa Dilaksanakan }\end{array}$} \\
\hline & $\begin{array}{l}\text { Labu Erlenmeyer, labu ukur, } \\
\text { gelas ukur, lampu Bunsen, } \\
\text { pipet tetes, gelas arloji, } \\
\text { corong, tabung reaksi, spatula, } \\
\text { statif, kaki tiga, kalorimeter, } \\
\text { thermometer, kawat kasa, } \\
\text { timbangan, botol semprot }\end{array}$ & $\begin{array}{l}\mathrm{HCl}, \mathrm{NaCl}, \\
\mathrm{Aquades}, \\
\mathrm{NaOH}, \\
\text { Indikator } \\
\text { universal }\end{array}$ & $\begin{array}{l}\text { Pengenalan dan } \\
\text { Identifikasi Alat dan } \\
\text { Bahan Kimia }\end{array}$ \\
\hline $2 \quad \begin{array}{l}\text { Kalorimeter, thermometer, } \\
\text { gelas ukur }\end{array}$ & $\begin{array}{l}\mathrm{HCl}, \mathrm{NaOH}, \\
\text { Aquades }\end{array}$ & Kalorimetri \\
\hline \multirow{2}{*}{$\begin{array}{l}\text { Gelas arloji, labu ukur, spatula, } \\
\text { timbangan, gelas kimia, pipet } \\
\text { tetes, botol semprot }\end{array}$} & $\begin{array}{l}\text { NaCl, } \\
\text { Aquades, } \\
\text { Sukrosa }\end{array}$ & Pembuatan larutan \\
\hline
\end{tabular}

Berdasarkan hasil analisis kegiatan laboratorium yang dapat dilakukan sesuai dengan RPS dan alat serta bahan yang tersedia di laboratorium IPA adalah pengenalan dan identifikasi alat dan bahan laboratorium, kalorimetri, dan pembuatan larutan.

b. Analisis Materi Kimia Dasar

Kegiatan parktikum kimia dasar tentunya harus disesuaikan dengan materi kimia dasar yang akan diajarkan. Oleh karena itu, sebelum menyusun kerangka panduan praktikum kimia dasar dilakukan analisis materi kimia dasar berdasarkan RPS yang telah disusun. Berdasarkan analisis materi kimia dasar yang ada di dalam RPS, kegiatan-kegiatan praktikum yang seharusnya dilakukan pada mata kuliah kimia dasar adalah pengenalan dan identifikasi alat dan bahan kimia, campuran homogen dan heterogen, pembuatan larutan, reaksi reduksi oksidasi, sel elektrokimia, kalorimetri, dan laju reaksi.

c. Studi Pendekatan SALINGTEMAS

Studi pendekatan SALINGTEMAS dilakukan untuk menentukan prinsip yang disesuaikan dengan prosedur setiap judul praktikum. Mahasiswa diharapkan tidak hanya memeliki pemahaman terkait pembuktian teori melalui kegiatan praktikum namun juga mampu mengaitkan apa yang ditemukan dalam kegiatan praktikum dengan Sains, Lingkungan, Teknologi, dan Masyarakat sehingga diperoleh pemahaman yang utuh dan bermakna. Karena pada dasarnya semua yang ada di dunia tidak terlepas dari yang namanya kimia dan pada dasarnya lingkungan yang tidak terlepas dari sains, teknologi, dan masyarakat merupakan sarana yang sangat baik dalam mempelajari kimia.

d. Menyusun Kerangka Pengembangan Panduan Praktikum Kimia Dasar Berbasis SALINGTEMAS

Penyusunan kerangka panduan praktikum Kimia Dasar mengacu pada hasil analisis kegiatan laboratorium, hasil analisis materi kimia dasar, dan hasil studi pendekatan SALINGTEMAS. Berdasarkan hasil dari ketiga hal ini disusunlah kerangka panduan praktikum kimia dasar. Namun, walaupun berdasarkan hasil analisis kegiatan laboratorium menunjukkan bahwa alat dan bahan yang tersedia dalam laboratorium belum memadai dan hanya dapat digunakan untuk tiga kegiatan praktikum, dalam penyusunan kerangka panduan praktikum kimia dasar ini tetap dilakukan penyusunan kerangka kegiata praktikum yang lengkap sesuai dengan hasil analisis materi kimia dasar dengan harapan dan keyakinan bahwa dengan berjalannya waktu akan terus diusahakan demi tersedianya alat dan bahan praktikum yang memadai untuk semua kegiatan praktikum yang ada pada materi kimia dasar. Pada tahap penyusunan kerangka panduan praktikum ini juga dilakukan pengumpulan referensi terkait dengan materi praktikum yang akan dilakukan. Pemilihan format panduan praktikum yang akan dikembangkan mengacu pada buku dan jurnal yang sebagai referensi terkait. 
e. Mengembangkan Panduan Praktikum Kimia Dasar Berbasis SALINGTEMAS Pengembangan panduan praktikum ini didesain berdasarkan format penulisan yang telah dipilih pada tahap penyusunan kerangka. Pada tahap ini menghasilkan draf 1 (desain awal panduan praktikum).

f. Meninjau dan Perbaiki Panduan Praktikum Kimia Dasar Berbasis SALINGTEMAS Pada tahap ini, meminta masukan dan saran dari teman sejawat mengenai desain awal panduan praktikum (draft 1). Sesuai dengan masukan dan saran dari teman sejawat tersebut, draft 1 kemudian direvisi sehingga menghasilkan draft 2 . Selanjutnya, draf 2 dinilai oleh validator ahli materi dalam segi kebenaran konsep materi. Draft 2 juga akan dinilai oleh validator ahli media dalam segi penampilan fisik dan kebahasaan. Kemudian draft 2 direvisi sesuai dengan hasil validasi tersebut sehingga akhirnya menghasilkan draf 3 . Draft 3 siap diimplementasikan pada tahap uji coba kepada mahasiswa S1 Pendidikan IPA Universitas Bhinneka PGRI.

g. Mengimplementasikan Panduan Praktikum Kimia Dasar Berbasis SALINGTEMAS Draf 3 diujicobakan kepada 5 mahasiswa program studi pendidikan IPA Universitas Bhinneka PGRI. Adapun tujuan dilaksanakannya uji coba ini untuk mengetahui penilaian mahasiswa sebagai user panduan praktikum kimia dasar berbasis SALINGTEMAS. Hasil dari tahap ujicoba ini berupa respon mahasiswa terhadap panduan praktikum yang telah dikembangkan.

Sebelum dilakukan validasi ahli materi, dilakukan revisi berdasarkan telaah dari teman sejawat pada draf 1 . Perbaikan atau revisi yang dilakukan:

1) Bahan larutan pada praktikum redoks dicantumkan konsentrasi

2) Tabel pengamatan pada praktikum redoks kata gelombang diganti gelembung Hasil revisi (draf 2) kemudian dinilai oleh validator ahli materi sampai menghasilkan draf 3 yang siap dan layak untuk diujicobakan. Penilaian kelayakan pada materi panduan parktikum kimia dasar berbasis SALINGTEMAS terdiri atas 10 poin penilaian terkait dengan kesahihan konsep dan keterlaksanaan praktikum. Rekap akhir hasil validasi ahli materi sampai akhirnya menghasilkan draf 3 dapat dilihat pada tabel 4 di bawah ini.

Tabel 4. Rekap Hasil Validasi Ahli Materi

\begin{tabular}{|c|c|c|}
\hline No. & Pernyataan & Skor \\
\hline 1 & $\begin{array}{l}\text { Materi pada panduan praktikum sesuai dengan materi pada mata } \\
\text { kuliah Kimia dasar }\end{array}$ & 5 \\
\hline 2 & $\begin{array}{l}\text { Urutan penyajian panduan praktikum sesuai dengan urutan materi } \\
\text { Kimia Dasar }\end{array}$ & 5 \\
\hline 3 & $\begin{array}{l}\text { Judul praktikum sesuai dengan tujuan, teori yang mendasari, alat dan } \\
\text { bahan, serta langkah kerja }\end{array}$ & 4 \\
\hline 4 & $\begin{array}{l}\text { Terdapat isian keterkaitan komponen SALINGTEMAS (Sains, } \\
\text { Teknologi, dan Masyarakat) pada masing-masing kegiatan praktikum }\end{array}$ & 4 \\
\hline 5 & $\begin{array}{l}\text { Panduan praktikum sesuai dengan format (Judul, Tujuan, Dasar Teori, } \\
\text { Alat dan Bahan, Langkah Kerja, Hasil Pengamatan, Analisis, Kaitan } \\
\text { SALINGTEMAS, dan Simpulan }\end{array}$ & 5 \\
\hline 6 & Panduan praktikum berisi kegiatan yang tidak membahayakan & 5 \\
\hline 7 & Alat dan bahan praktikum mudah didapatkan & 4 \\
\hline 8 & Alokasi waktu sesuai dengan kegiatan praktikum & 4 \\
\hline 9 & $\begin{array}{l}\text { Kegiatan praktikum memberikan pengalaman langsung bagi } \\
\text { mahasiswa }\end{array}$ & 4 \\
\hline \multirow[t]{3}{*}{10} & Langkah kerja runtut & 4 \\
\hline & Total & 44 \\
\hline & Persentase (\% & \\
\hline
\end{tabular}

Berdasarkan rekap akhir hasil penilaian ahli materi diperoleh persentase 44:50 $x 100 \%=88 \%$ seperti tertera pada tabel 4 . Hasil penilaian tersebut masuk dalam kategori sangat layak untuk produk yang dikembangkan (Murdiani, 2012). Pernyataan sangat layak oleh 2 validator ahli materi masih disertai saran perbaikan untuk 
pengembangan produk yaitu perlu adanya penyertaan diagram langkah kerja dalam panduan praktikum tersebut.

Penilaian kelayakan oleh ahli media berisi 9 poin penilaian terkait dengan tampilan fisik dan kebahasaan. Setelah dilakukan perbaikan pada halaman sampul, rekap akhir hasil validasi oleh validator ahli media dapat dilihat pada tabel 5 di bawah ini.

Tabel 5. Rekap Hasil Validasi Ahli Media

\begin{tabular}{clc}
\hline No. & \multicolumn{1}{c}{ Pernyataan } & Skor \\
\hline 1 & Gambar sampul pedoman praktikum sesuai dengan materi kimia dasar & 4 \\
\hline 2 & Penggunaan jenis huruf yang tidak terlalu banyak pada desain sampul & 4 \\
\hline 3 & Ukuran huruf yang digunakan sesuai proporsi & 4 \\
\hline 4 & Penampilan fisik panduan praktikum menarik & 4 \\
\hline \multirow{2}{*}{5} & $\begin{array}{l}\text { Panduan praktikum sesuai dengan format (Judul, } \\
\text { Tujuan, Dasar Teori, Alat dan Bahan, Langkah Kerja, Hasil Pengamatan, } \\
\text { Analisis, Kaitan SALINGTEMAS, dan Simpulan }\end{array}$ & 5 \\
\hline 6 & Bahasa yang digunakan sesuai dengan PUEBI & 4 \\
\hline 7 & Bahasa yang digunakan interaktif dan komunikatif & 5 \\
\hline 8 & $\begin{array}{l}\text { Bahasa yang digunakan tidak menimbulkan makna } \\
\text { ganda (ambigu) }\end{array}$ & 4 \\
\hline 9 & Bahasa yang digunakan jelas dan mudah dipahami & $\mathbf{3 8}$ \\
\hline & Total \\
\hline
\end{tabular}

Berdasarkan rekap akhir hasil penilaian ahli media diperoleh persentase 38:45 $\mathrm{x}$ $100 \%=84 \%$ seperti tertera pada tabel 4 . Hasil penilaian tersebut masuk dalam kategori sangat layak. Pernyataan sangat layak oleh 2 validator ahli media masih disertai saran perbaikan untuk pengembangan produk yaitu perlu adanya ketelitian dalam penulisan dan ejaan panduan praktikum yang telah dikembangkan.

Pada tahap uji coba dilakukan 1 kali praktikum yang berjalan dengan lancar. Pelaksanan praktikum ini disesuaikan dengan alat dan bahan yang tersedia di laboratorium dan situasi di masa pandemi. Angket respon mahasiswa dibagikan saat uji coba terbatas. Hasil rekapitulasi angket respon mahasiswa dapat dilihat pada tabel 6 di bawah ini.

Tabel 6. Rekap Hasil Angket Mahasiswa

\begin{tabular}{|c|c|c|c|c|c|c|}
\hline \multirow{2}{*}{ No. } & \multirow{2}{*}{ Pernyataan } & \multicolumn{5}{|c|}{ Skor Responden } \\
\hline & & A & B & C & D & $\mathbf{E}$ \\
\hline 1 & $\begin{array}{l}\text { Panduan praktikum dapat digunakan sebagai } \\
\text { sumber belajar }\end{array}$ & 4 & 4 & 3 & 4 & 3 \\
\hline 2 & Materi praktikum mudah dipahami & 3 & 3 & 4 & 4 & 3 \\
\hline 3 & $\begin{array}{lll}\text { Panduan praktikum memudahakan } & \text { dalam } \\
\text { menyusun rumusan masalah } & \\
\end{array}$ & 3 & 4 & 3 & 3 & 3 \\
\hline 4 & $\begin{array}{lll}\text { Panduan praktikum } & \text { memudahakan } & \text { dalam } \\
\text { menyusun hipotesis } & & \\
\end{array}$ & 3 & 4 & 3 & 3 & 3 \\
\hline 5 & $\begin{array}{l}\text { Langkah kerja dalam panduan praktikum mudah } \\
\text { dipahami }\end{array}$ & 4 & 4 & 4 & 4 & 3 \\
\hline 6 & $\begin{array}{l}\text { Terdapat kesesuaian antara panduan praktikum } \\
\text { dengan pelaksanaan praktikum }\end{array}$ & 3 & 4 & 3 & 3 & 3 \\
\hline 7 & Panduan praktikum mudah dipahami & 3 & 3 & 3 & 3 & 3 \\
\hline 8 & Data hasil praktikum sesuai denfan langkah kerja & 3 & 3 & 3 & 4 & 3 \\
\hline 9 & Data hasil praktikum dapat dianalisis & 3 & 4 & 3 & 4 & 3 \\
\hline 10 & $\begin{array}{l}\text { Materi praktikum dapat dikaitkan dengan komponen } \\
\text { SALINGTEMAS }\end{array}$ & 3 & 4 & 3 & 4 & 3 \\
\hline 11 & Hipotesis dijadikan & 4 & 4 & 3 & 3 & 3 \\
\hline
\end{tabular}




\begin{tabular}{|c|c|c|c|c|c|c|}
\hline \multirow{2}{*}{ No. } & \multirow{2}{*}{ Pernyataan } & \multicolumn{5}{|c|}{ Skor Responden } \\
\hline & & $\mathbf{A}$ & B & C & D & E \\
\hline & \multicolumn{6}{|l|}{ kesimpulan } \\
\hline 12 & $\begin{array}{l}\text { Panduan praktikum membantu terlaksananya } \\
\text { kegiatan praktikum dengan baik }\end{array}$ & 4 & 3 & 4 & 3 & 3 \\
\hline \multicolumn{2}{|c|}{ Persentase (\%) } & 83 & 92 & 81 & 88 & 75 \\
\hline \multicolumn{2}{|c|}{ Persentase rata-rata (\%) } & & & 84 & & \\
\hline
\end{tabular}

Berdasarkan rekap akhir hasil angket respon, mahasiswa memberikan respon positif terhadap panduan praktikum yang telah dikembangkan. Perhitungan persentase respon 5 mahasiswa berturut-turut adalah 83\%, 92\%, 81\%, 88\%, dan $75 \%$. Skor rata-rata secara keseluruhan panduan praktikum kimia dasar sebesar $84 \%$ yang artinya berada pada kriteria sangat layak dengan fitur-fitur yang ada di dalam panduan praktikum tersebut yaitu meliputi gambar yang menarik, penggunaan jenis huruf, ukuran huruf, penampilan fisik, terdapat isian keterkaitan komponen SALINGTEMAS, dan bahasa yang digunakan sesuai dengan PUEBI, mudah dipahami, interaktif dan komukatif, serta tidak menimbulkan penafsiran ganda. Mahasiswa diharapkan meningkatkan kemampuan dan rasa percaya diri dalam melaksanakan kegiatan praktikum agar mendapatkan pemahaman yang utuh tentang ilmu kimia sekaligus sebagai pondasi dalam mempelajari kimia melalui panduan praktikum kimia dasar yang telah dikembangkan (American Chemical Society, 2009).
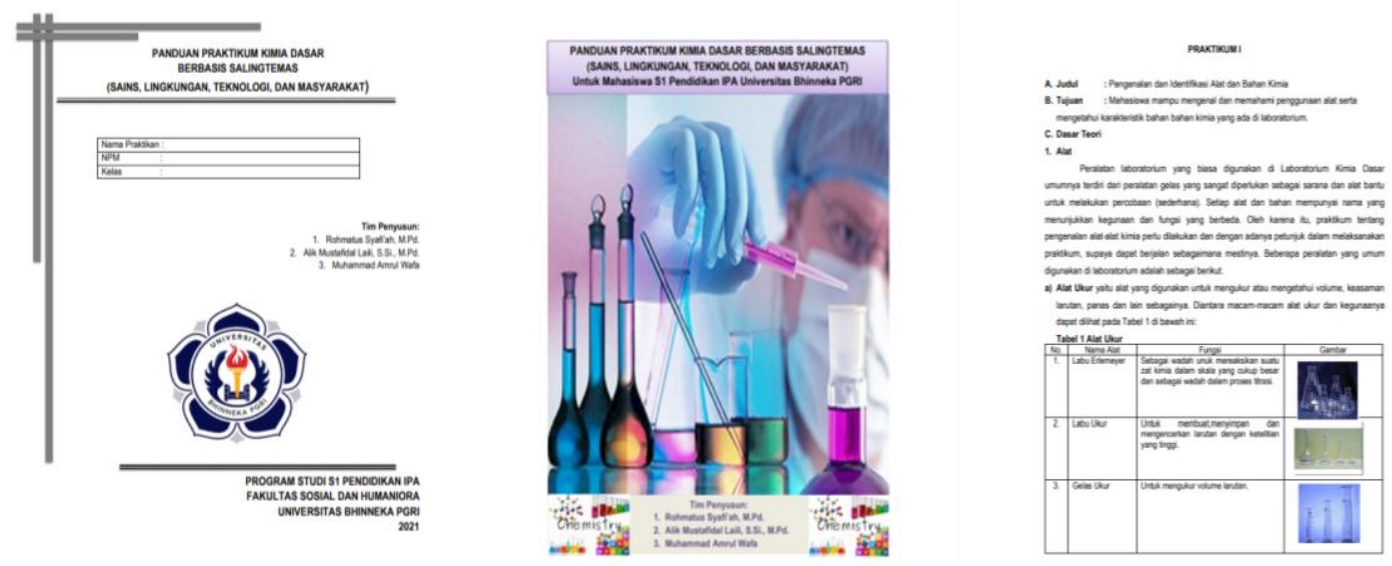

\section{KESIMPULAN}

Berdasarkan hasil angket respon mahasiswa skor rata-rata secara keseluruhan sebesar $84 \%$. Artinya panduan praktikum kimia dasar berbasis SALINGTEMAS ini sangat layak digunakan dalam proses pembelajaran.

\section{SARAN}

Limitasi dalam studi ini yaitu hanya mengambil 6 materi dari keseluruhan materi kimia dasar (Pengenalan dan Identifikasi Alat dan Bahan Kimia, Campuran homogen dan Heterogen, Pembuatan Larutan, Reaksi Reduksi Oksidasi, Sel Elektrokimia, Kalorimetri (Penentuan Kalor Jenis Logam), dan Laju Reaksi. Pada penelitian selanjutnya bisa dikembangkan panduan praktikum yang sama dengan pendekatan yang berbeda dan materi yang sama, atau bisa juga dikembangkan panduan praktikum dengan matyeri yang berbeda tetapi dengan pendekatan yang sama yaitu SALINGTEMAS. 


\section{DAFTAR RUJUKAN}

Achmad, H dan Baradja, L. 2012. Demonstrasi Sains Kimia : Kimia Deskriptif Melalui Demo Kimia. Bandung : Nuansa.

American Chemical Society. (2009). ACS Guidelines for Chemistry inTwo-Year College Programs: Spring 2009. Washington, DC: American Chemical Society

Arifin, M. dkk. 2000. Strategi Belajar Mengajar Kimia. Bandung: Jurusan Pendidikan Kimia FPMIPA UPI

Asmaningrum, dkk. 2018. Pengembangan Panduan Praktikum Kimia Dasar Terintegrasi Etnokimia untuk Mahasiswa. Jurnal Tadris Kimiya Vol 3 No. 2. https://journal.uinsgd.ac.id/index.php/tadris-kimiya/article/view/3205/pdf

Binadja, A. 1999. Pendidikan SETS (Science, Environmenr, Tecnology, and Society) Penerapannya pada Pengajaran (SETS Education Coverage Science and Non Science

BNSP. 2006. Standar Isi Untuk Satuan Pendidikan Dasar dan Menengah. Jakarta: Badan Standar Nasional Pendidikan.

Lee, William L dan Owens, Diana L. 2004. Multimedia-based Instructional Design: Computer-based. San Francisco: John Wiley \& Sons.

Magwilang, E.B. 2016. Teaching Chemistry in Context: Its Effects on Students'Motivation, Attitudes and Achievement in Chemistry. International Journal of Learning, Teaching and Educational Research, Vol.15, No.4, 60-68.

Mahfuzah, dkk. 2018. "Efektivitas GDL (Guided Discovery Learning) dan Problem Solving terhadap KBK (Keterampilan Berpikir Kritis) dan HOTS (Higher Order Thingking Skills"). Jurnal Pendidikan: Teori, Penelitian, dan Pengembangan Volume: 3 Nomor: 6 Bulan Juni Tahun 2018 Halaman: 739-744. Diakses melalui http://journal.um.ac.id/index.php/jptpp/ EISSN: 2502-471X tanggal 25 Januari 2020.

Murdiani, I. (2012). Pembelajaran Biologi Menggunakan Metode E-learning Berbasis Multiple Intelligences pada Materi Sistem Gerak Manusia.

Murti, S., Muhibbuddin, \& Nurmaliah, C. 2014. "Penerapan Pembelajaran Berbasis Pratikum Untuk Meningkatkan Kemampuan Kognitif dan Psikomotorik Pada Perkuliahan Anatomi Tumbuhan". Jurnal Biologi Edukasi. Diakses melalui http://jurnal.unsyiah.ac.id/JBE/article/view/2268 tanggal 24 Januari 2020.

Pekdag, B. 2010. Alternative Method in Learning Chemistry: Learning with Animation, Simulation, Video and Multimedia, Journal of Turkish Science Education, 7(2): 111-118

Prayitno, Trio A. 2017. "Pengembangan Petunjuk Praktikum Mikrobiologi Program Studi Pendidikan Biologi". Jurnal Biota Vol 3 No 1. Diakses melalui http://jurnal.radenfatah.ac.id/index.php/biota/article/view/tap tanggal 25 Januari 2020.

Rismawati. 2012. Pengembangan Penuntun Praktikum Alternatif Sederhana Sebagai Pendamping Penuntun Praktikum Standar Kimia SMA Kelas XI. Tesis. Medan: Program Pascasarjana Universitas Negeri Medan

Sanjaya, I.G.M dan Trisanti, D.C. dan. 2013. "Pengembangan Media Permainan Stoichio Game pada Materi Pokok Konsep Mol bagi Siswa SMA Sekolah 
Lensa (Lentera Sains): Jurnal Pendidikan IPA

Vol. 11, No. 2, hlm. 73-82, 2021

Berstandar Internasional". Journal of Chemical Education. 2, (2), 181-187.

Setiawan, E. 2014. Kamus Besar Bahasa Indonesia. (online) http://kamusbahasaindonesia

Sugiyono. 2017. Metode penelitian pendidikan pendekatan kuantitatif, kualitatif, dan R\&D.Bandung: Alfabeta 